Janusz Kozana

Stanisław Rzadkosz

Aldona Garbacz-Klempka

Marcin Piękoś

Witold Cieślak

\title{
THE INFLUENCE OF SELECTED ALLOYING ELEMENTS ON THE MICROSTRUCTURE, SELECTED MECHANICAL AND TECHNOLOGICAL PROPERTIES OF BRASSES
}

\author{
WPŁYW WYBRANYCH DODATKÓW STOPOWYCH \\ W KSZTAŁTOWANIU MIKROSTRUKTURY, \\ WYBRANYCH WŁAŚCIWOŚCI MECHANICZNYCH \\ I TECHNOLOGICZNYCH MOSIĄDZÓW
}

\section{Abstract}

The research aimed at assessing the influence of alloying elements, such as $\mathrm{Al}, \mathrm{Si}, \mathrm{Ni}, \mathrm{Pb}$ and $\mathrm{Bi}$ on the chosen alloys of $\mathrm{Cu}-\mathrm{Zn}$. Microstructures were examined with the use of optical and scanning microscopy with X-ray microanalysis. The properties of the received alloys were determined with regard to changes in the mechanical parameters, namely $R_{m}, A_{5}, H B$, also, machinability changes were assessed as well as proclivity to hot fracturing of Cu-Zn alloys with additives of lead and bismuth. The results indicate the possibility of obtaining very high mechanical properties: $R_{m}$ up to $700 \mathrm{MPa}$, hardness within the range of $130-180 \mathrm{HB}$ and $A_{5}$ from 3 to $30 \%$. Also, in the case of the researched alloys, the machining and hot fracturing results look promising.

Keywords: $\mathrm{Cu}-\mathrm{Zn}$ alloys, mechanical properties, technological properties, alloying additives

\section{Streszczenie}

Podjęte badania miały na celu określenie oddziaływania dodatków stopowych, takich jak: Al, Si, Ni, Pb i Bi w wybranych stopach Cu-Zn. Przeprowadzono badania mikrostruktur z wykorzystaniem mikroskopii świetlnej oraz mikroskopii skaningowej z mikroanalizą rentgenowską. Określono właściwości otrzymanych stopów pod względem zmian takich parametrów mechanicznych jak: $R_{m}, A_{5}$, HB oraz poddano ocenie zmiany skrawalności i skłonności do pęknięć na gorąco stopów Cu-Zn z dodatkami ołowiu i bizmutu.

Otrzymane wyniki wskazują na możliwości uzyskania stopów o bardzo wysokich właściwościach mechanicznych, takich jak: wytrzymałość na rozciąganie do $700 \mathrm{MPa}$, twardość w zakresie 130-180 HB oraz wydłużenie w zakresie 3-30\%. Korzystnie przedstawiają się również wyniki oceny skrawalności oraz pęknięć na gorąco.

Słowa kluczowe: stopy Cu-Zn, właściwości mechaniczne, właściwości technologiczne, dodatki stopowe 


\section{Introduction}

Among metal alloys used in casting a very important group consists of copper alloys. Depending on the additions, these alloys can be divided into bronzes and brasses. Brasses, which are the alloys of copper with zinc as the main alloying element, constitute one of the most important groups. In many cases brasses have properties resembling those of bronzes and are their cheaper, but equivalent substitutes. To all intents and purposes, all copper alloys as-cast have soft and plastic matrix, which consists of solid solution crystallites. At their boundaries there are hardening phase elements in peritectic form or free intermetallic phases. By using the chosen alloying elements in optimal quantities it is possible to obtain the brasses with very high machining, technological and utility properties [1-5].

\section{Methodology and conditions of research}

The results presented in this article were obtained as part of the research conducted at the Laboratory of Non-Ferrous Metals Foundry, at the Faculty of Foundry Engineering of the AGH in Krakow.

The melts were obtained from an induction furnace.

As the stock the following materials were used:

- electrolytic cathodic copper in the form of plates, the minimum copper content of 99,99\% according to PN-EN 1978 ,

- electrolytic zinc Z1 according to PN EN 1179,

- electrolytic aluminium AR1, according to PN EN 573-3,

- electrolytic nickel 99,93, according to EN 10204 3.1.B,

- initial alloys of CuNi10 and CuSi16,

- refining bismuth and lead.

The prepared alloys were cast into metal moulds, taking care to preserve the conditions of melting and casting for the successive casts.

From the obtained experimental casts the samples were prepared for the planned research.

Metallographic tests were carried out with the help of optical and scanning microscopy, as well as chemical composition was tested, using, among other methods, Scanning Electron Microscopy with X-ray microanalysis (SEM-EDS). Machinability was determined with the help of Keep-Bauer method, also the susceptibility to hot fracturing of the chosen brasses with the addition of lead and bismuth was compared.

\section{The research of aluminium-silicon-nickel brasses}

In order to determine the influence of the chosen alloying elements in multicomponent brass, a succession of melts with determined content was planned. The planned and received content of the alloying additions is shown in Tables 1 and 2.

In further part of the article, in Figures 1-8, sample microstructures of the examined alloys are presented.

The microstructures of the CuZn34AISiNi alloys with varied content of alloy additions presented in Figures 1-8, show mainly the $\alpha$ phase precipitates against the background of $\beta$ '. The changeability of the alloy content causes distinct changes in the microstructures, both with respect to the amount of $\alpha$ phase precipitates (distinctly seen comparing Figs 4 and 6) as well as to the size reduction of the $\beta$ ' phase (Fig. 7, sample M7). Because of the complex composition of the alloys, the X-ray microanalysis was performed for the precipitates visible. The results of this examination are presented in Figures 9-10 and in Table 3. 
Table 1. The planned content of the alloying elements

\begin{tabular}{|c|c|c|c|c|}
\hline \multirow{2}{*}{ No. } & \multicolumn{4}{|c|}{ CuZn34AISiNi } \\
\cline { 2 - 4 } & \multicolumn{3}{|c|}{ wt.\% } & \multirow{2}{*}{ Cast number } \\
\cline { 2 - 5 } & $\mathrm{Al}$ & $\mathrm{Si}$ & $\mathrm{Ni}$ & \\
\hline 1 & 1.8 & 1.2 & 2 & $\mathrm{M} 3$ \\
\hline 2 & 1.2 & 1.2 & 2 & $\mathrm{M} 2$ \\
\hline 3 & 1.2 & 0.8 & 2 & $\mathrm{M} 1$ \\
\hline 4 & 1.8 & 0.8 & 2 & $\mathrm{M} 7$ \\
\hline 5 & 1.8 & 1.2 & 3 & $\mathrm{M} 6$ \\
\hline 6 & 1.2 & 1.2 & 3 & $\mathrm{M} 5$ \\
\hline 7 & 1.2 & 0.8 & 3 & $\mathrm{M} 4$ \\
\hline 8 & 1.8 & 0.8 & 3 & $\mathrm{M} 8$ \\
\hline
\end{tabular}

Table 2. The received content of the alloying elements

\begin{tabular}{|c|c|c|c|c|}
\hline \multirow{2}{*}{ No. } & \multicolumn{4}{|c|}{ CuZn34AISiNi } \\
\cline { 2 - 4 } & \multicolumn{3}{|c|}{ wt.\% } & \multirow{2}{*}{ Cast number } \\
\cline { 2 - 5 } & $\mathrm{Al}$ & $\mathrm{Si}$ & $\mathrm{Ni}$ & \\
\hline 1 & 1.84 & 1.22 & 1.98 & $\mathrm{M} 3$ \\
\hline 2 & 1.22 & 1.26 & 2.10 & $\mathrm{M} 2$ \\
\hline 3 & 1.17 & 0.82 & 2.08 & $\mathrm{M} 1$ \\
\hline 4 & 1.82 & 0.76 & 2.07 & $\mathrm{M} 7$ \\
\hline 5 & 1.81 & 1.24 & 2.97 & $\mathrm{M} 6$ \\
\hline 6 & 1.16 & 1.17 & 2.90 & $\mathrm{M} 5$ \\
\hline 7 & 1.19 & 0.83 & 3.11 & $\mathrm{M} 4$ \\
\hline 8 & 1.86 & 0.84 & 3.02 & $\mathrm{M} 8$ \\
\hline
\end{tabular}

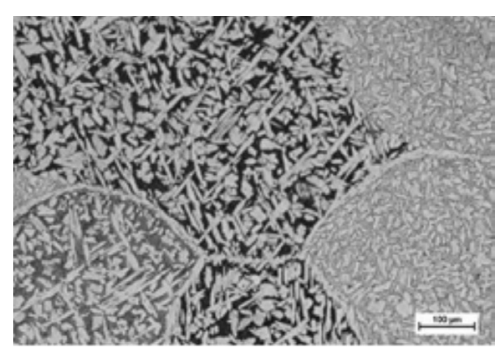

Fig. 1. M1 alloy microstructure, magnification $100 x$

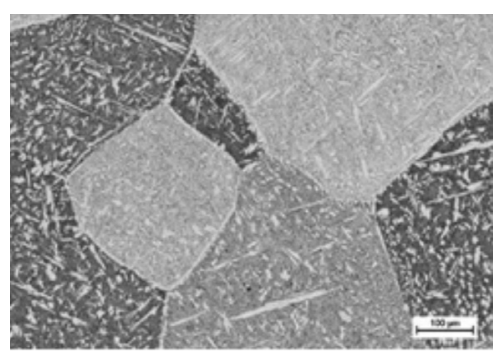

Fig. 3. M3, alloy microstructure, magnification $100 x$

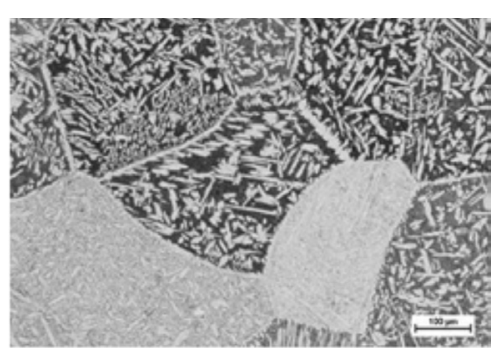

Fig. 2. M2 alloy microstructure, magnification $100 x$

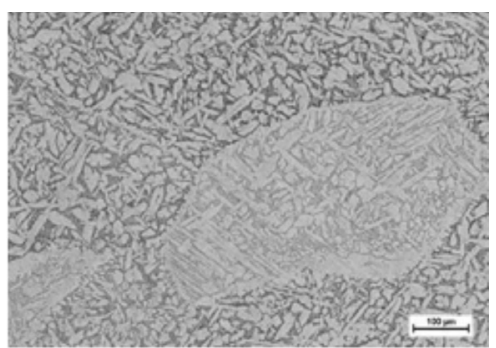

Fig. 4. M4 alloy microstructure, magnification $100 x$ 


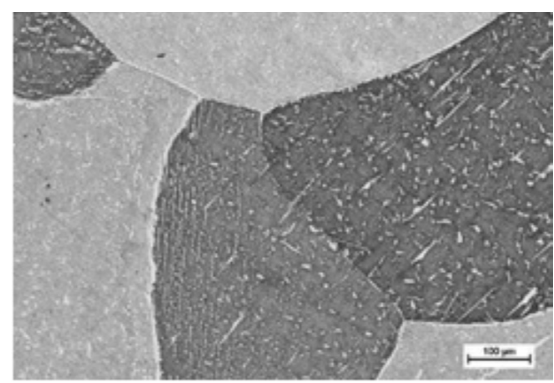

Fig. 6. M6 alloy microstructure, magnification $100 x$

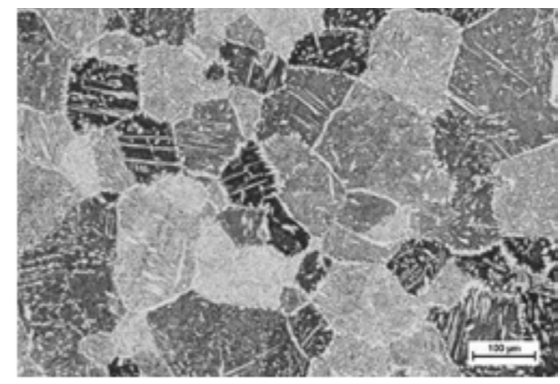

Fig. 7. M7 alloy microstructure, magnification $100 x$

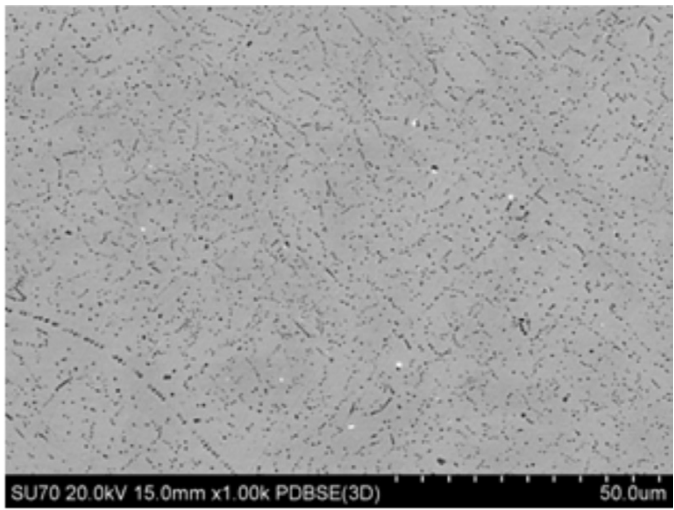

Fig. 9. The surface of the M8 (SEM) with the help of reflected electrons (PDBSE)

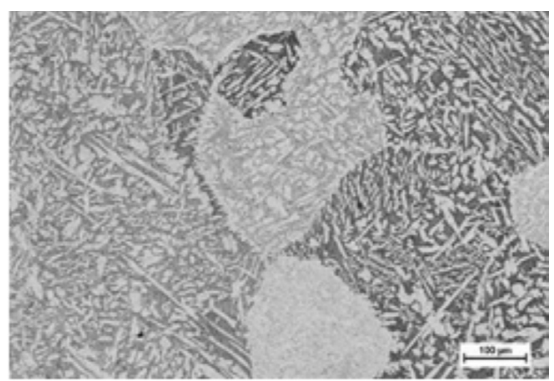

Fig. 5. M5 alloy microstructure, magnification $100 x$

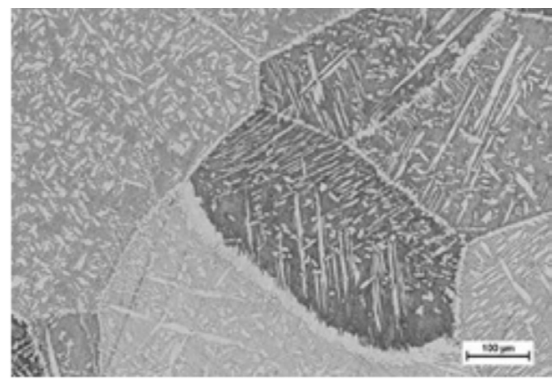

Fig. 8. M8 alloy microstructure, magnification $100 x$

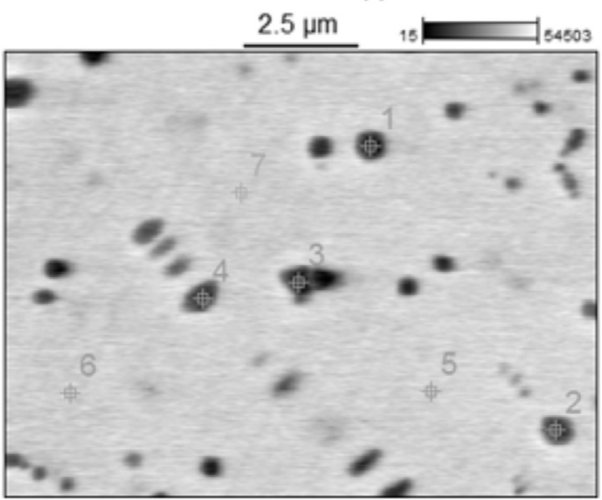

Fig. 10. The surface of the M8 with the microanalysis points marked.

Analysing the microanalysis results it can be noticed that the aluminium and silicon additions present in the alloy, to a small degree solve in the matrix. Greater amounts of these elements were discovered in the spherical precipitates with nickel as multicomponent phases of the NiSi or NiAl type. The presence of a significant amount of copper and zinc in the microanalysis results can be connected with the matrix influence, which consists mainly of zinc and copper ( $\alpha+\beta$ ' phase). This initial hypothesis concerning the kind of precipitates should be verified with the help of X-ray diffraction. 
Table 3. Microanalysis results for points from sample M8 (Fig. 10), wt.\%

\begin{tabular}{|c|c|c|c|c|c|}
\hline No. & $\mathrm{Al}$ & $\mathrm{Si}$ & $\mathrm{Ni}$ & $\mathrm{Cu}$ & $\mathrm{Zn}$ \\
\hline pt1 & 6.768 & 4.379 & 22.179 & 41.656 & 25.018 \\
\hline pt2 & 6.699 & 4.165 & 15.185 & 47.111 & 26.839 \\
\hline pt3 & 7.656 & 5.505 & 28.093 & 37.929 & 20.817 \\
\hline pt4 & 5.769 & 3.377 & 12.688 & 49.243 & 28.923 \\
\hline pt5 & 1.110 & 0.575 & 0.897 & 61.629 & 35.789 \\
\hline pt6 & 0.895 & 0.378 & 0.750 & 66.611 & 31.366 \\
\hline pt7 & 0.889 & 0.429 & 0.698 & 66.170 & 31.814 \\
\hline
\end{tabular}

Having completed the microstructural analysis and having recorded the changes, the tests of basic mechanical properties were conducted for the alloys researched. The results of these investigations are presented in Table 4.

Table. 4. Mechanical properties of the examined alloys

\begin{tabular}{|c|c|c|c|c|}
\hline No. & $\begin{array}{c}\mathrm{R}_{\mathrm{m}} \\
{[\mathrm{MPa}]}\end{array}$ & $\begin{array}{c}\mathrm{A}_{5} \\
{[\%]}\end{array}$ & $\mathrm{HB}$ & $\begin{array}{c}\text { Cast } \\
\text { number }\end{array}$ \\
\hline 1 & 683 & 14 & 179 & $\mathrm{M} 3$ \\
\hline 2 & 373 & 5.6 & 153 & $\mathrm{M} 2$ \\
\hline 3 & 298 & 5 & 146 & $\mathrm{M} 1$ \\
\hline 4 & 614 & 15.7 & 179 & $\mathrm{M} 7$ \\
\hline 5 & 566 & 13.7 & 186 & $\mathrm{M} 6$ \\
\hline 6 & 520 & 10 & 145 & $\mathrm{M} 5$ \\
\hline 7 & 659 & 29.5 & 130 & $\mathrm{M} 4$ \\
\hline 8 & 558 & 3 & 158 & $\mathrm{M} 8$ \\
\hline
\end{tabular}

Analysing the results of the microstructure as well as the strength tests it can be concluded, that the varied amounts of the chosen alloying additions have evident influence on the microstructural elements causing, at the same time, a change in mechanical properties. Within the range of the used additions of aluminium, silicon and nickel it is possible to achieve alloys with hardness reaching $180 \mathrm{HB}$, plasticity - up to $30 \%$ and tensile strength - up to $700 \mathrm{MPa}$. Apart from mechanical properties an important role is played by the features which influence the machinability of a given alloy. In the further part of this article the machining properties of some chosen CuZn alloys are presented.

\section{The influence of bismuth as an alloying element improving the machinability of brasses}

As part of the research the bismuth influence was evaluated within the range of up to $4 \%$, in the alloys with the microstructure from the boundary of the $\beta^{\prime} / \gamma$ phases. The melts were prepared, samples made, microscopy investigation was carried out and the hardness of the alloys in question was determined. The results of the microstructural investigations are presented in Figures 11-16 and in Table 5. 


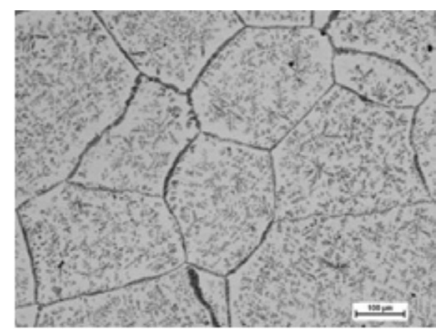

Fig. 11. CuZn52 alloy microstructure, magnification 100x

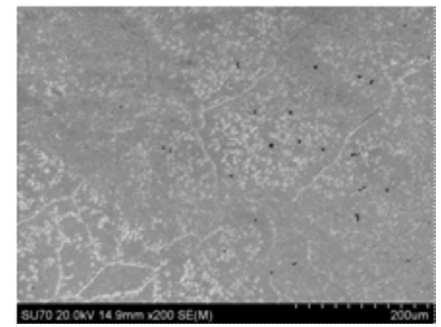

Fig. 14. The surface of the sample CuZn52Bi4 (SEM)

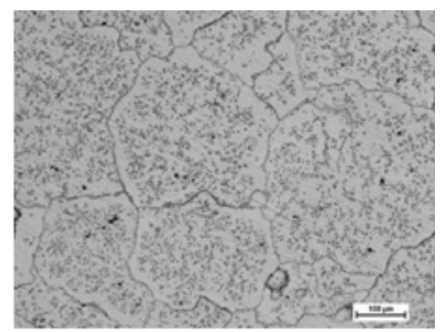

Fig. 12. CuZn52Bi4 alloy microstructure, magnification $100 x$

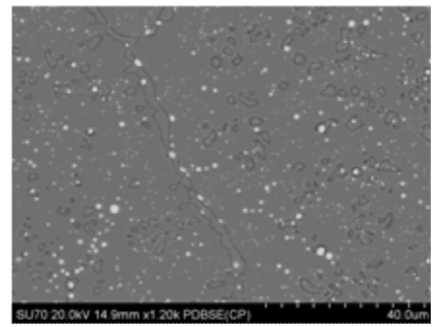

Fig. 15. The surface of the sample CuZn52Bi4 (PDBSE)

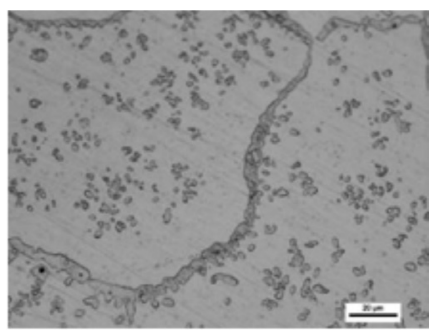

Fig. 13. CuZn52Bi4 alloy microstructure, magnification $100 \mathrm{x}$

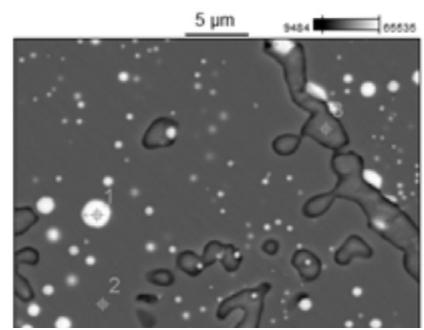

Fig. 16. The surface of the CuZn52Bi4 sample with the microanalysis points marked

Table 5. Microanalysis results for the points from alloy sample CuZn52Bi4 (Fig. 16)

\begin{tabular}{|c|c|c|c|}
\hline No. of sample & $\mathrm{Cu}[\mathrm{wt} \%]$ & $\mathrm{Zn}[\mathrm{wt} \%]$ & $\mathrm{Bi}[\mathrm{wt} \%]$ \\
\hline $\mathrm{pt} 1$ & 5.751 & 6.031 & 88.217 \\
\hline $\mathrm{pt} 2$ & 51.686 & 48.314 & - \\
\hline $\mathrm{pt3}$ & 42.988 & 57.012 & - \\
\hline
\end{tabular}

Analysing the results of the bismuth addition on the microstructure and properties, it can be concluded that there is a slight decrease in the number of $\gamma$ phase precipitates visible at the grain boundaries and size reduction of this phase inside the grains. The Figure of the sample surface (SE) definitely shows a uniform spacing of the spherical bismuth precipitates on the whole surface of the analysed sample. From the hardness changes graph (Fig. 17) it can be seen that after adding bismuth the hardness of the tested alloy decreases as the amount of $\mathrm{Bi}$ increases, reaching the value below $140 \mathrm{HB}$ at $4 \% \mathrm{Bi}$.

The form and placement of bismuth in the microstructure of the brass analysed pointed to the validity of the further research in order to determine the influence of this addition on the machining properties.

The machinability assessment was conducted with the help of Keep-Bauer method, based on drilling a hole with constant advancing force. According to this method the machinability indicator is the time necessary for the drill's tip to cover a certain distance, or the other way round - the distance travelled by the drill's tip during a certain time. If the material being machined is not homogeneous or if the wear of the cutting edge is very intense then on the machining distance-time chart the angle pitch of the curve will undergo changes, in step with the changes in machining of the material. The tests were carried out with constant parameters: the drill bit $\varnothing 5 \mathrm{~mm}$ - a new one for each sample, the rotational velocity of the drill's spindle $680 \mathrm{rpm}$, the advancing force $-500 \mathrm{~N}$. During the tests the shift of the drilling bit was recorded in time. The curves showing the drilling characteristics are shown in Figure 18. 


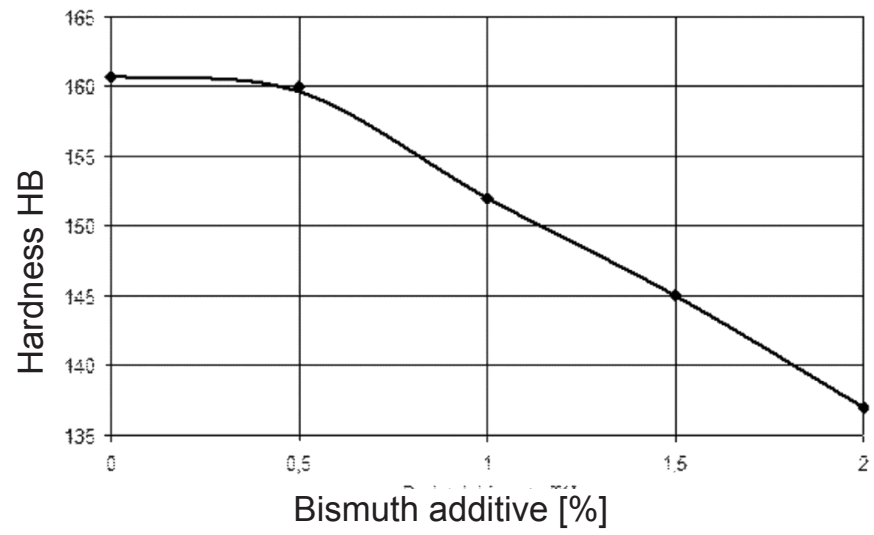

Fig. 17. The influence of bismuth additive on HB of the CuZn52 brass

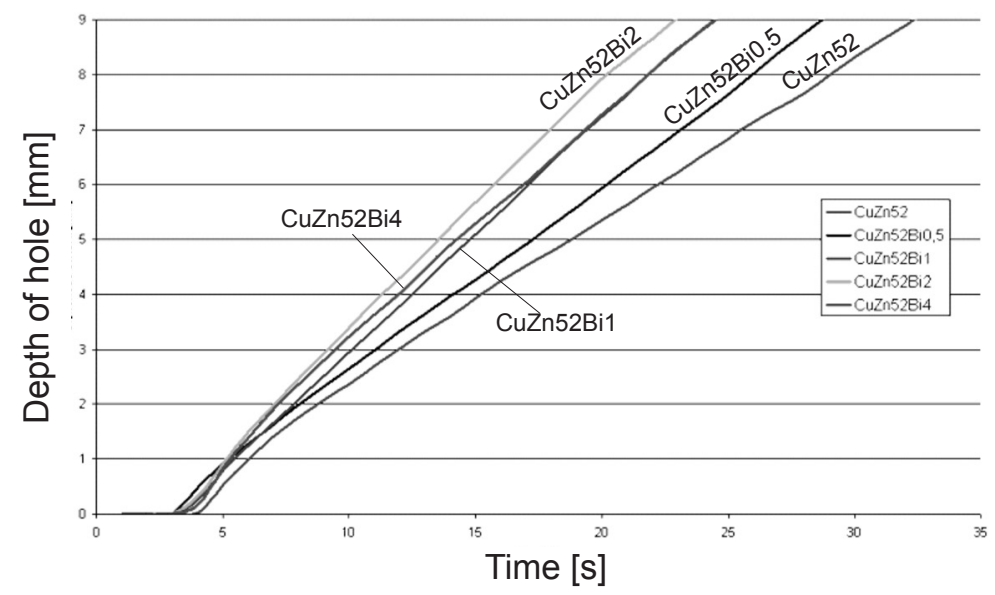

Fig. 18. Exemplary curves of drilling characteristics

The machinability tests conducted according to the method described, show a positive influence of bismuth additive in the CuZn52 alloys on the speed of hole drilling with a constant advancing force. At the same time it can be concluded, based on the research conducted, that bismuth addition above $2 \%$ does not significantly increase the cutting speed of the material tested.

From the point of view of machinig properties another important aspect is the form and shape of the chips produced during the machining process. Examples of chips created during our tests are shown in Figures 19-22.

The conducted tests show that copper and zinc alloys are characterised by different kinds of chips created during the machining process. During drilling the brasses with a phase microstructure, long, tapered, helical chips are created (Fig. 19). As the zinc content increases in the CuZn alloys, this is the alloys with $\beta$ ' and $\gamma$ phase microstructure, short, tapered helical chips are produced. The bismuth additions used in our research caused length decrease of the helical chips, which facilitates removing them from the hole drilled and, at the same time, it reduces machining resistance. 


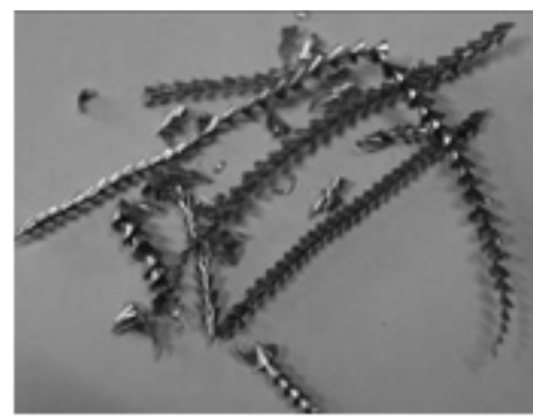

Fig. 19. Sample of chips CuZn34 alloys

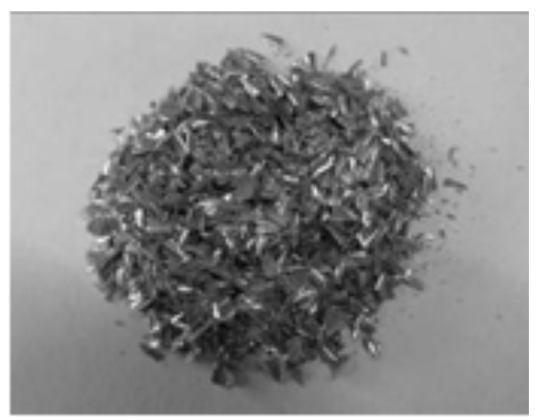

Fig. 21. Sample of chips CuZn44Bi0,5 alloys

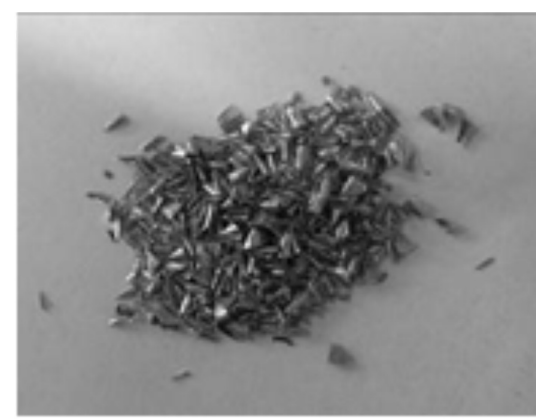

Fig. 20. Sample of chips CuZn44 alloys

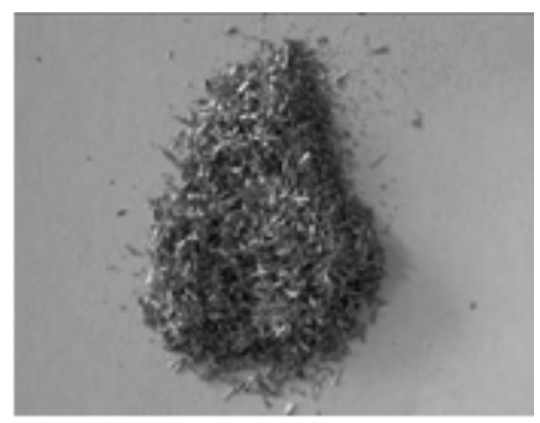

Fig. 22. Sample of chips CuZn44Bi4 alloys

\section{The analysis of hot tears}

Hot fracturing occurs when an alloy solidifies; when it is in semi-solid state and individual solid state crystals grow together and their immediate contact is broken by a film of liquid alloy. The cast then has low strength and low plasticity, and, as a result, even slight hindering of the shrinkage can cause fracturing.

In order to determine bismuth influence on hot tear of the chosen brasses, research was carried out into the alloys with changed content of the main elements, with the addition of bismuth and lead. The samples were cast into a metal mould, inside which thermally insulating pads were placed (Fig. 23). This kind of construction results in the fact that the stresses created in the solidifying cast create fractures in the middle section of the mould (Fig. 24) (the area with the isolating pads).

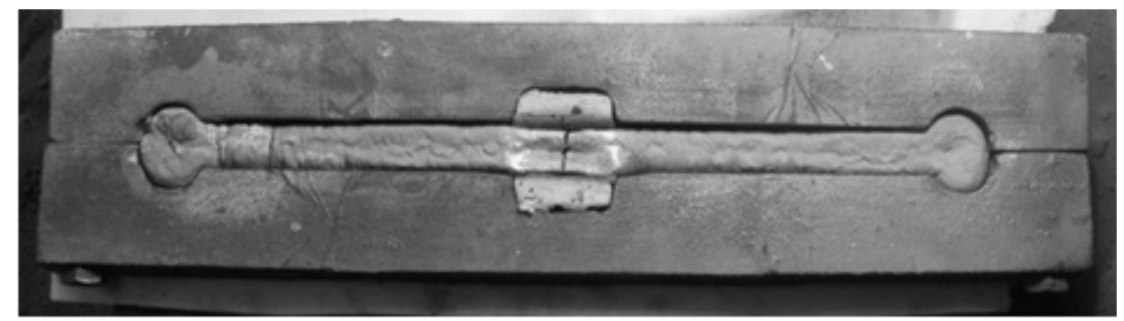

Fig. 23. Metal mould for researching hot tears 


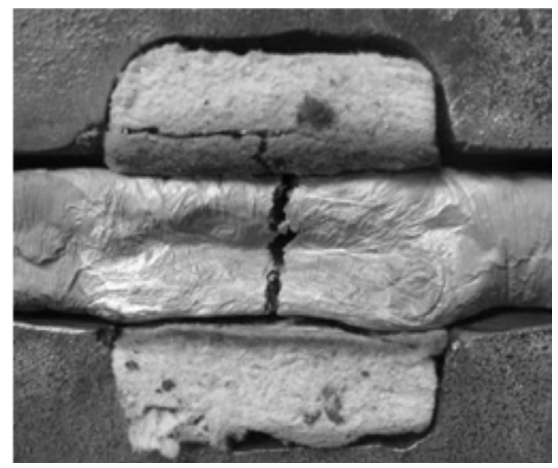

Fig. 24. Sample crack received

The initial research of the CuZn34 and CuZn40 alloys, following the method described above, showed that bigger zinc contents in brass limit the occurrence of hot cracking. As the next stage, the influence of bismuth and, for comparison, lead additions was investigated for the CuZn34 alloy.

The received results do not show a significant influence of these elements on increasing the fracturability of the alloys examined.

The chosen surface figures with visible dendrites are shown in Figure 25.

The received results do not show a significant contribution of the additions used towards the increase of hot fracturing of the alloys examined.

a)

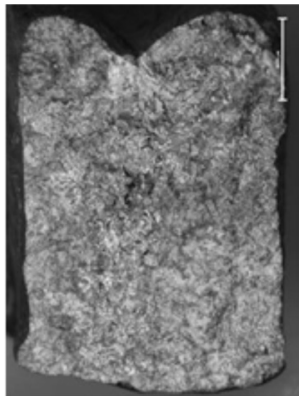

b)

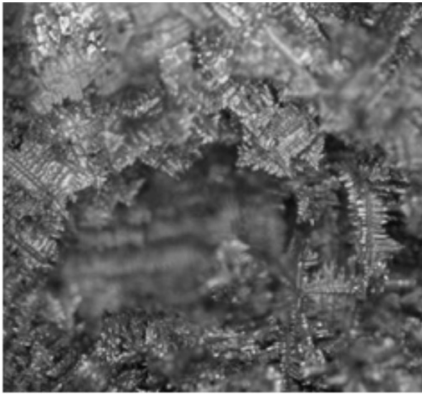

c)

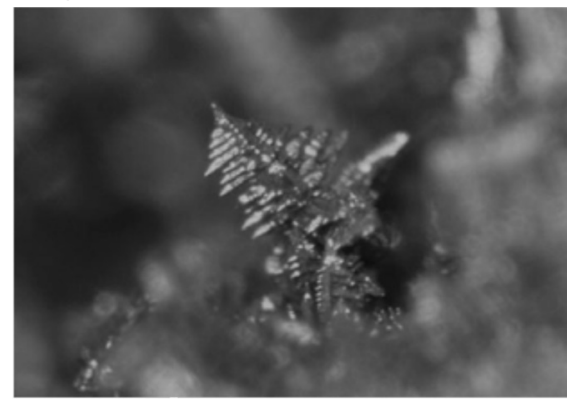

Fig. 25. Examples of sample surface resulting from hot fracturing: a) main view of surface, b) surface with dendrites visible, $c$ ) the single dendrite

\section{Conclusions}

The researched influence of the addition of aluminium, silicon and nickel in multicomponent brasses points to the possibilities of obtaining multicomponent alloys based on the CuZn matrix, characterised by very high mechanical properties. In the process of influencing the alloy properties, an important role is played by bismuth, as an alloying element. Based on the investigations carried out it can be concluded, that it improves the machinability of the CuZn alloys and, at the same time, it does not have negative impact with regard to hot tear of the alloys analysed. 


\section{References}

[1] Kozana J., Rzadkosz S., Piękoś M.: Assessment of aluminium and silicon influence on strength properties and a microstructure of nickel brasses. Archives of Foundry Engineering, 8, 4, 2008, pp. 81-86

[2] Miernik M.: Skrawalność metali. Metody określania i prognozowania. Wydawnictwo Politechniki Wrocławskiej, Wrocław 2000

[3] Adamski C., Rzadkosz S.: Metalurgia i odlewnictwo metali nieżelaznych. Stopy cynku oraz stopy miedzi. Wydawnictwa AGH, Kraków 1992

[4] Dobrzański L. A.: Metalowe materiały inżynierskie. WNT, Warszawa 2004

[5] Rzadkosz S., Cieślak W., Piękoś M., Kozana J.: Effect of modification on the intercrystalline cracks forming in CuZn38PbAl brass castings. XXVII konferencja naukowa z okazji Święta Odlewnika 2003, pp. 47-52 